Ekspansi: Jurnal Ekonomi, Keuangan, Perbankan dan Akuntansi

ISSN (Online): 2580-7668 ISSN (Print): 2085-5230

Vol. 11, No. 1 (Mei 2019), Hal. 55 - 76

\title{
DIGITALISASI KEUANGAN SYARIAH MENUJU KEUANGAN INKLUSIF: KERANGKA MAQASHID SYARIAH
}

\author{
Irfan Nurfalah $^{1}$, Aam Slamet Rusydiana ${ }^{2}$ \\ ${ }^{1}$ PT. Bank BNI Syariah, Jakarta, Indonesia \\ ${ }^{2}$ STEI Tazkia Universitas, Bogor, Indonesia \\ Email Korespondensi: irfan.nurfalah@gmail.com
}

\begin{abstract}
Sharia financial literacy and financial inclusion in indonesia are still in the lower level, Indonesian's Financial Services Authority launched in 2016 that the data of sharia financial literacy is about $8.11 \%$ and sharia financial inclusion only about $11.06 \%$. This problem can be overcome by combining financial services and products with the latest technology. The industrial revolution 4.0 facilitate people to access all information with smartphones connected to the internet. This is an opportunity for the Islamic finance industry to innovate digitally. The author makes a digital innovation solution to accommodate these opportunities, namely "Connected, One Stop Solution" with 20 features that can be enjoyed by all segments of society. This study uses a qualitative analysis method that explains the suitability of 20 application features with the concept of maqashid sharia (Dharuriyyah, Hajiyat and Tahsiniyat) and analyse the implications of digital applications on sharia financial literacy and inclusion. The division of the dharuriyyah is categorized into 5 basic namely 1) Religion, 2) Soul, 3) Descendants, 4) Intellect and 5) Assets. The results of the study indicate that the digital innovation of "Connected, One Stop Solution" is appropriate with the concept of maqashid sharia and could help increase the level of sharia financial literacy and inclusion as well as support halal needs according to maqashid sharia
\end{abstract}

Keywords: Digitalization, Financial Inclusion, Islamic Finance, Maqashid Shariah

Abstrak: Tingkat literasi dan inklusi keuangan syariah di Indonesia masih tergolong rendah, data Otoritas Jasa Keuangan (OJK) tahun 2016 menunjukkan bahwa tingkat literasi keuangan syariah sekitar $8,11 \%$ dan tingkat inklusi keuangan syariah sekitar 11,06\%. Rendahnya akses masyarakat ini dapat diatasi dengan mengombinasikan layanan dan produk keuangan dengan teknologi terkini. Revolusi industri 4.0 memudahkan masyarakat untuk mengakses segala informasi dengan smartphone yang terkoneksi dengan internet. Hal ini menjadi peluang bagi industri keuangan syariah untuk berinovasi secara digital. Penulis membuat solusi inovasi digital untuk mewadahi peluang tersebut yaitu aplikasi "Connected, One Stop Solution" dengan 20 fitur yang dapat dinikmati oleh seluruh golongan masyarakat. Penelitian ini menggunakan metode analisis kualitatif yang menjelaskan kesesuaian 20 fitur aplikasi dengan konsep maqashid syariah (Dharuriyyah, Hajiyat dan Tahsiniyat) dan menganalisis implikasi aplikasi digital terhadap literasi dan inklusi keuangan syariah. Pembagian dharuriyyah dikategorikan menjadi 5 dasar yaitu 1) Agama, 2) Jiwa, 3) Keturunan, 4) Akal dan 5) Harta. Hasil penelitian menunjukkan bahwa inovasi digital "Connected, One Stop Solution" telah sesuai dengan konsep maqashid syariah dan dapat membantu meningkatkan tingkat literasi dan inklusi keaungan syariah serta mendukung kebutuhan halal sesuai maqashid syariah.

Kata Kunci: Digitalisasi, Inklusi Keuangan, Keuangan Syariah, Maqashid Shariah

DOI: 10.35313/ekspansi.v11i1.1205

Riwayat Artikel:

Diterima: $19-11-2018$

Direvisi: 5 - 3- 2019

Disetujui: 4 - 4 - 2019 


\section{PENDAHULUAN}

Ketidakmerataan akses terhadap perbankan di antara daerah perkotaan dan pedesaan menyebabkan rendahnya tingkat inklusi dan literasi keuangan. Berdasarkan data World Bank tahun 2011 tingkat kepemilikan akun perbankan orang Indonesia sekitar 20\% dari total penduduk, selanjutnya pada tahun 2014 meningkat menjadi sekitar 36\% dari total penduduk dan pada tahun 2017 kembali mengalami peningkatan menjadi sekitar 49\%. Walaupun terjadi peningkatan yang cukup baik, tetapi jika dilihat nilai rata-rata pertumbuhan kepemilikan akun perbankan tahun 2011-2017 hanya sekitar 14,5\% artinya masih banyak orang Indonesia yang belum mendapatkan akses terhadap perbankan. (https://globalfindex.worldbank.org)

Hal ini dikuatkan oleh penelitian Sanjana dan Nursechafia (2016) bahwa faktor yang paling mempengaruhi tingkat inklusi keuangan di Indonesia yaitu aksesibilitas masyarakat terhadap perbankan sedangkan indikator availabilitas dan penggunaan tidak begitu berpengaruh. Pada tahun 2016, Otoritas Jasa Keuangan (OJK) membuat survey terkait inklusi dan literasi keuangan Indonesia dan hasilnya 29.66\% tingkat literasi keuangan dan $67.82 \%$ tingkat inklusi keuangan masyarakat Indonesia. Tetapi hasil ini merupakan keseluruhan dari semua institusi keuangan, sedangkan untuk tingkat literasi keuangan syariah hanya $8.11 \%$ dan tingkat inklusi keuangan syariah sekitar $11.06 \%$. (www.ojk.go.id)

\section{Gambar 1. Indeks Literasi dan Inklusi Keuangan Syariah Indonesia}

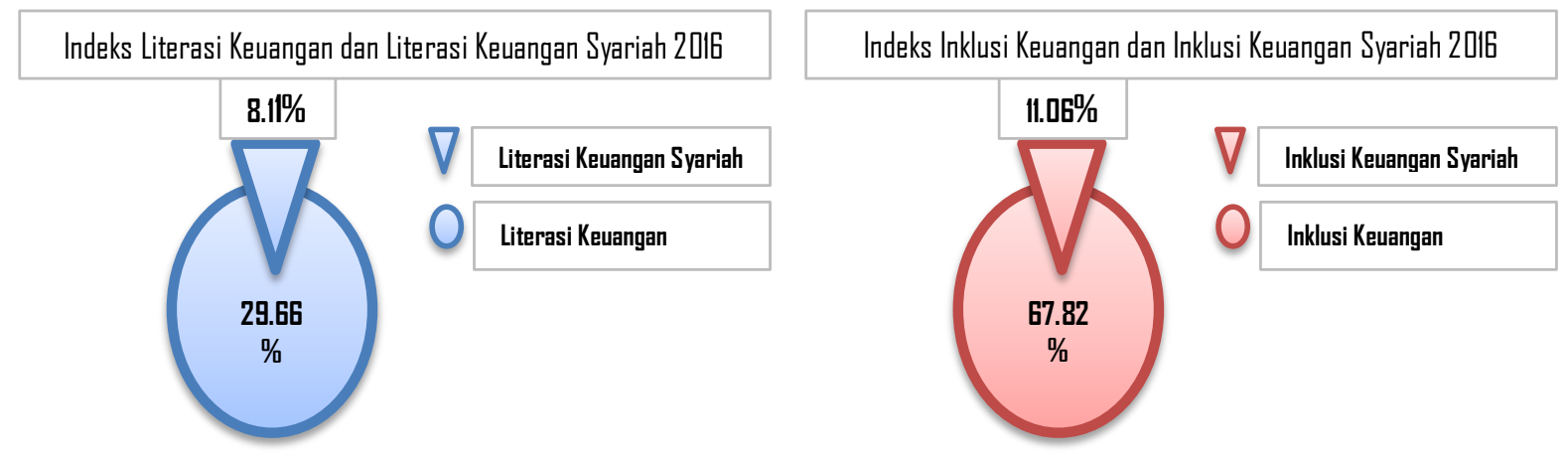

Sumber: Otoritas Jasa Keuangan (2017), data diolah

Data tersebut membuktikan bahwa tingkat literasi dan tingkat inklusi keuangan syariah masih sangat rendah, maka dari itu perlu ada pendekatan khusus agar masyarakat mengetahui produk dan layanan keuangan syariah. Salah satu pendekatan yang dapat dilakukan oleh perusahaan dan praktisi keuangan syariah adalah memanfaatkan teknologi digital sebagai sarana untuk meningkatkan akses masyarakat terhadap produk dan layanan keuangan syariah.

Teknologi digital saat ini berkembang cukup pesat, hal ini ditandai dengan revolusi industri 4.0 di mana industri mengembangkan dan memanfaatkan teknologi untuk membantu mempermudah operasionalnya. Sektor industri yang mengembangkan teknologi digital dalam bisnisnya, sebagian besar diprakarsai oleh perusahaan ecommerce, start-up Financial Technology (fintech) baik itu peer to peer lending ataupun crowd funding. 
Pertumbuhan konsumsi masyarakat terhadap internet dan smartphone menjadi indikator yang baik dalam mengembangkan layanan dan produk keuangan syariah berbasis digital agar bisa menjangkau ke seluruh wilayah di Indonesia. Pemanfaatan teknologi ini harus segera dilakukan agar terciptanya inklusi keuangan yang lebih merata dan menyeluruh khususnya untuk produk dan layanan keuangan syariah. Data menunjukkan bahwa adanya peningkatan penggunaan internet dan smartphone di Indonesia setiap tahunnya, databoks katadata.com menyebutkan bahwa terjadi peningkatan yang sangat signifikan untuk penggunaan smartphone di Indonesia dari tahun 2011-2017 sebesar 432\%.

Gambar 2. Pengguna Internet dan Smartphone di Indonesia

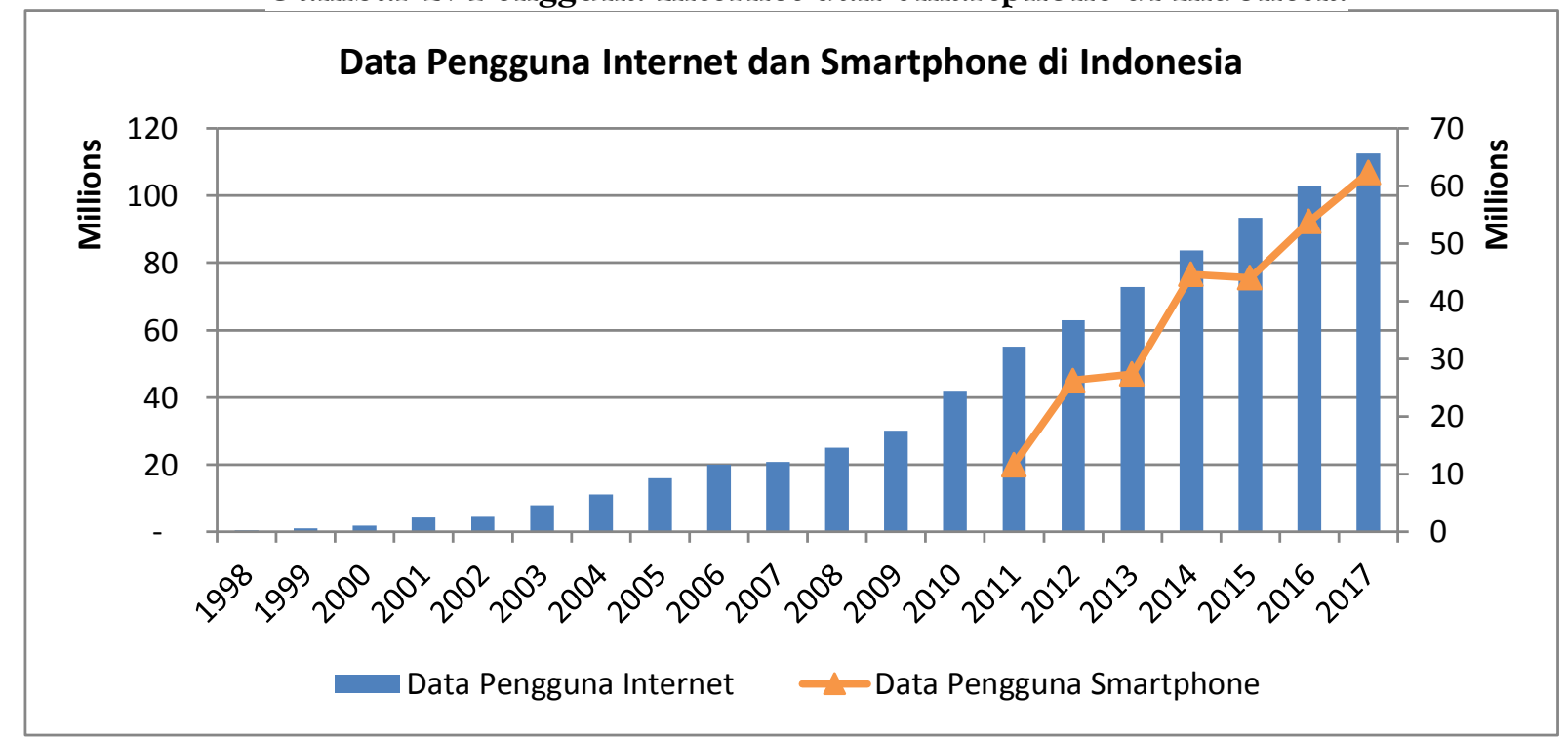

Sumber: databoks katadata.co.id 2018, data diolah

Pertumbuhan ini menjadi kesempatan dan tantangan bagi perusahaan-perusahaan keuangan syariah untuk segera beralih ke layanan digital. Berdasarkan survey yang dilakukan oleh Sharing Vision tahun 2015 tentang alat pembayaran yang sering digunakan masyarakat dalam transaksi online yaitu transfer online via ATM sebesar $42 \%$, internet banking sebesar 28\%, transfer langsung ke rekening sebesar 25\%. (https://sharingvision.com) Survey ini membuktikan bahwa potensi masyarakat untuk beralih dari transaksi offline menuju transaksi online cukup besar dan ini didukung pula dengan pertumbuhan perusahaan start-up keuangan berbasis aplikasi digital di Indonesia.

Seperti kita ketahui, saat ini potensi pengembangan industri keuangan syariah berbasis perusahaan fintech atau teknologi keuangan di Indonesia cukup terbuka dan potensial. Meskipun menurut penelitian yang dilakukan Rusydiana (2018), terdapat beberapa kendala yang masih dihadapi seperti kurangnya instrumen kebijakan yang menjaga proses kerja fintech dari hulu ke hilir, demikian juga ketersediaan sumber daya manusia untuk fintech yang mumpuni. Sementara menurut Webster dan Pizalla (2015) persaingan antara fintech dan layanan keuangan tradisional relatif semakin intens setiap tahun karena terus berkembangnya teknologi informasi. 
Sementara itu, fintech di Indonesia mulai berkembang dari tahun 2006 dengan jumlah perusahaan pada awalnya hanya 4 perusahaan saja dan berkembang menjadi 16 perusahaan di tahun 2007. Perkembangan signifikan terjadi pada tahun 2015-2016 di mana jumlah perusahaan yang menjalankan model bisnis fintech sekitar 165 perusahaan.

Gambar 3. Perkembangan Perusahaan Fintech di Indonesia

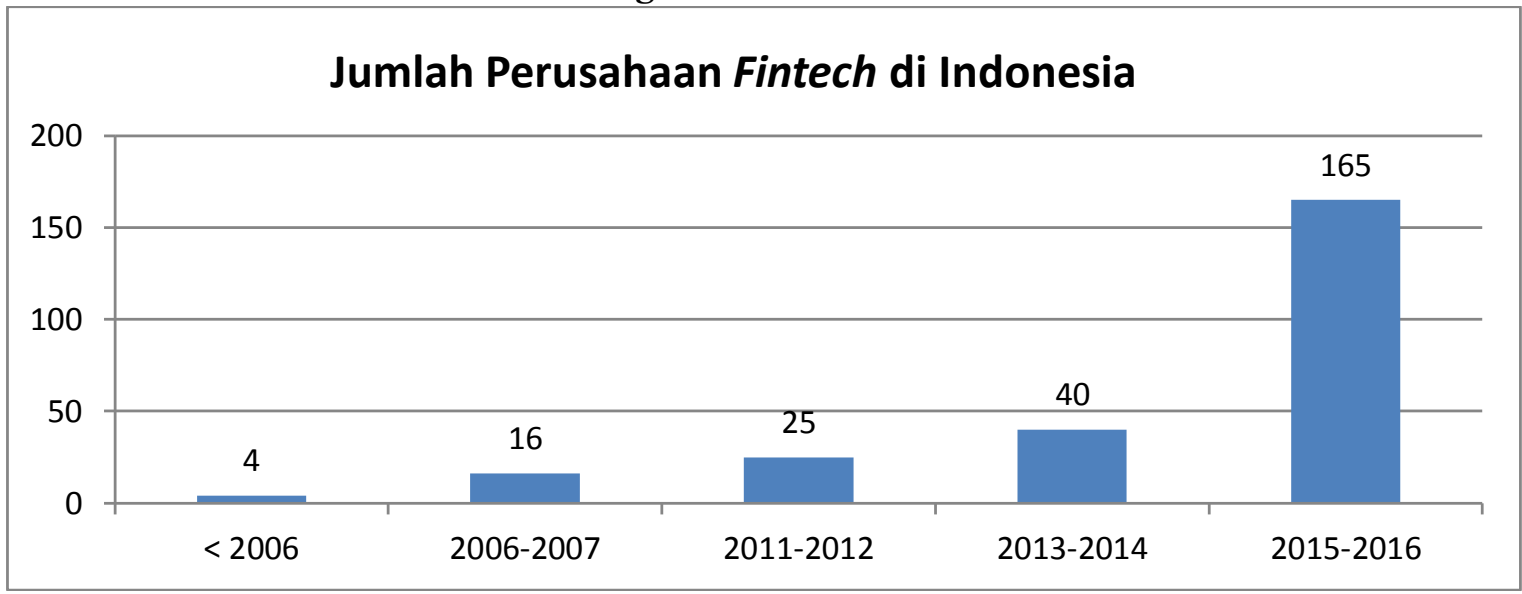

Sumber: D. Hadad 2017, data diolah

Berdasarkan data OJK, perusahaan fintech di Indonesia terbagi kepada beberapa sektor yaitu: 1) financial planning, 2) Crowdfunding, 3) Lending, 4) Aggregator, 5) Payment, dan 6) fintech lainnya. Hadad (2017) menerangkan bahwa perusahaan fintech di Indonesia didominasi oleh sektor pembayaran (payment) sebesar $42.22 \%$, sektor pinjaman (lending) $17.78 \%$, sektor aggregator sebesar $12.59 \%$, sektor perencanaan keuangan (financial planning) sebesar $8.15 \%$, sektor crowdfunding sebesar $8.15 \%$ dan sektor fintech lainnya sebesar $11.11 \%$.

Sistem keuangan syariah yang digabungkan dengan teknologi harus sesuai dengan stadarisasi akad-akad keaungan syariah karena konsep keuangan syariah berbeda dengan konsep keuangan konvensional, dalam konsep keuangan syariah transaksi yang mengandung maysir,gharar, tadlis, ikhtikar dan riba tidak diperbolehkan. Selain itu, dalam pelaksaannya setiap transaksi yang dilakukan harus mengacu kepada tujuan utama syariah yaitu maqashid syariah. Maka setiap inovasi produk dan layanan keuangan syariah harus mempertimbangkan ke dua hal tersebut. Ismail (2014) menyimpulkan pembagian maqashid syariah menjadi tiga kategori yaitu dharuriyat, hajiyat dan tahsiniyat. Maslahah dharuriyyat disebut juga dengan maqashid al-khamsah yaitu agama (al-Din), Jiwa (al-Nafs), Keturunan (al-Nasl), Akal (al-'Aql) dan Harta (al-Mal). Maslahah hajiyat untuk menghilangkan kesempitan dan kesulitan dalam penenuhan kebutuhan dasar manusia. Maslahah tahsiniyat adalah segala sesuatu yang bertujuan untuk menjaga kehormatan dari maqashid al-khamsah tersebut. (Ismail, 2014) Maka, inovasi fintech untuk keuangan syariah harus berlandaskan maqashid syariah yang tertuang dalam Al-Qur'an dan Hadits.

Dari latar belakang ini, semakin terbukanya informasi publik dan semakin mudahnya akses masyarakat terhadap internet maka peluang untuk mengembangkan 
inovasi produk dan layanan keuangan syariah berbasis digital sangat potensial dan pengembangan ini juga dapat meningkatkan tingkat literasi dan inklusi keuangan syariah khususnya bagi masyarakat di daerah terpencil. Penulis tertarik untuk meneliti permasalahan literasi dan inklusi keuangan syariah dan solusinya dengan mengembangkan inovasi produk dan layanan syariah secara digital. Rumusan masalah dalam penelitian ini yaitu 1) Solusi apa yang diberikan untuk meningkatkan rendahnya tingkat literasi dan inklusi keuangan syariah di Indonesia, 2) Apakah solusi tersebut sesuai dengan konsep maqashid syariah, 3) Apa implikasinya terhadap keuangan syariah.

\section{TINJAUAN PUSTAKA}

\subsection{Inklusi Keuangan}

Keuangan inklusif merupakan bentuk pendalaman keuangan (financial sercive deepening) yang ditujukan untuk seluruh golongan masyarakat khususnya masyarakat kelas bawah agar dapat mengakses produk dan jasa keuangan formal dengan lebih mudah dan terjangkau seperti menabung, menyimpan uang yang aman (keeping), transfer, pinjaman dan asuransi. Indeks yang digunakan untuk mengukur inklusi keuangan terdiri dari tiga faktor utama yaitu akses, penggunaan dan kualitas. (www.bi.go.id)

The Consultative Group to Assist the Poor (CGAP-GPFI) mendefinisikan keuangan inklusif adalah suatu kondisi di mana semua orang berusia kerja mampu mendapatkan akses yang efektif terhadap kredit, tabungan, sistem pembayaran dan asuransi dari seluruh penyedia layanan finansial. Akses yang efektif juga termasuk layanan yang nyaman dan bertanggung jawab, pada harga yang terjangkau untuk masyarakat dan berkelanjutan untuk penyedia. Diharapkan pada akhirnya, masyarakat dapat memanfaatkan layanan finansial yang formal daripada layanan finansial yang informal. (www.cgap.org)

Otoritas Keuangan dalam hal ini Bank Indonesia (BI) dan Otoritas Jasa Keuangan $(\mathrm{OJK})$ mencanangkan strategi nasional keuangan inklusif yang dijabarkan dalam 6 pilar yaitu: 1) edukasi keuangan, 2) fasilitas keuangan publik, 3) pemetaan informasi keuangan, 4) kebijakan atau peraturan pendukung, 5) fasilitas intermediasi dan distribusi, dan 6) perlingungan konsumen. Sasaran utama dari perumusan 6 pilar ini adalah kepada 2 kelompok masyarakat yaitu kelompok masyarakat pekerja/buruh migran dan penduduk daerah terpencil dengan 4 klasifikasi yaitu masyarakat sangat miskin, miskin bekerja/produktif, hampir miskin dan tidak miskin. Penentuan sasaran ini diharapkan dapat meningkatkan akses 2 kelompok tersebut terhadap produk dan layanan keuangan secara keseluruhan. Jika masyarakat sudah dapat mengakses produk dan layanan keuangan dengan mudah, maka masyarakat akan lebih produktif dan berdaya beli sehingga tujuan dari perumusan pilar-pilar strategi keuangan inklusif ini akan tercapai yaitu 1) Pemerataan pendapatan di seluruh wilayah Indonesia dari sabang sampai merauke, 2) Secara organik akan mengurangi tingkat kemiskinan di daerah, 3) akan tercipta sistem keuangan yang stabil. 


\section{Gambar 4. Strategi Nasional Keuangan Inklusif}



Sumber: Booklet Keuangan Inklusif, Dept. Pengembangan Akses Keuangan \& UMKM BI: 2014.

\subsection{Digitalisasi dan Fintech}

Sejak tahun 1980-an trend digitalisasi mulai diperbincangkan, saat itu komputer rumah mulai diperkenalkan ke pasar konsumen, hal ini membuat informasi semakin terbuka dan konsumen dapat dengan mudah mengakses isu-isu terbaru. Digitalisasi membuat tidak adanya hambatan dalam memperoleh informasi-informasi dan memberikan ruang yang lebih banyak untuk kebebasan berinteraksi dengan berbagai pihak tanpa memandang ruang dan waktu. (Koiranen, Rasanen \& Sodegarrd, 2010).

Digitalisasi dapat didefinisikan sebagai penggunaan teknologi digital untuk model bisnis baru dan memberikan peluang baru yang menghasilkan nilai. Hal ini merupakan bisnis digital dan integrasi teknologi digital ke dalam kehidupan sehari-hari (Gartner, 2016). Digitalisasi adalah peluang bagi perusahaan dan organisasi untuk meningkatkan aktivitas bisnis mereka. Di era digitalisasi dan otomatisasi banyak pekerjaan kantor dapat diproduksi lebih efisien dan dengan biaya rendah (Schinkel, 2000). Digitalisasi dapat dilihat sebagai peluang untuk meningkatkan hubungan pelanggan, proses bisnis, menciptakan dan mengadaptasi model bisnis baru (Schumann \& Tittmann, 2015).

Pada sektor keuangan, digitalisasi merupakan sebuah pengembangan untuk metode kerja, ruang lingkup kerja dan lingkuangan kerja. Kemajuan teknologi informasi dan sistem komputerisasi yang dikembangkan menjadi digitalisasi dapat 
membuat pekerjaan menjadi lebih efesien dan cepat. Konsensus umum adalah bahwa karena digitalisasi, pelanggan akan menjadi lebih mandiri dan lingkungan kerja berubah menjadi lingkungan yang lebih digital, yang dapat mengubah seluruh organisasi. Telecommuting dan bekerja jarak jauh dari kantor akan menjadi lebih banyak metode kerja saat ini dan di masa depan, keterampilan digital menjadi semakin penting dan menjadi kebutuhan tenaga kerja. (Finanssialan keskusliitto, 2015).

Digitalisasi sistem keuangan dan teknologi disebut Financial Technology (fintech) yang merupakan inovasi sistem keuangan secara digital agar masyarakat dapat dengan mudah mengakses produk dan layanan keuangan dan melemahkan barrier to entry (Bank Indonesia, 2016). KPMG mengartikan industri teknologi keuangan sebagai bisnis berbasis teknologi yang bersaing, atau berkolaborasi dengan lembaga keuangan (Pollari, 2016). Dalam pengertian yang berbeda, Chuen dan Teo (2015) menjelaskan bahwa fintech mengacu pada layanan keuangan atau produk inovatif yang disampaikan melalui teknologi baru. Perkembangan fintech ini merubah pola model bisnis keuangan saat ini dimana melemahnya barrier to entry memberikan peran bagi fintech dalam memunculkan perilaku unregulated yang menjalankan model bisnis layaknya perusahaan atau institusi regulated. (Bank Indoensia, 2016).

Perkembangan fintech di dunia sudah dimulai sejak tahun 1800-an dengan munculnya telegraph dan semakin berkembang pada tahun-tahun selanjutnya khususnya pada era digital saat ini. Tahun 1900-an mulai berkembang Automated Teller Machine (ATM), Clearing House, Internet Banking dan Paypal. Kemudian semakin berkembang dengan adanya Apple Pay, Samsung Pay, Smile to Pay (Alibaba) pada tahun 2000-an. (Zimmerman, 2016). Di Indonesia perkembangan fintech jenis pembayaran semakin berkembang pesat, baik yang diterbitkan oleh lembaga keuangan seperti unikQu, Tbank, Ecash maupun yang diterbitkan oleh start-up fintech seperti Go-Pay dan OVO.

Menurut Otoritas Jasa Keuangan (2016), kelebihan dari fintech adalah: 1) Melayani masyarakat Indonesia yang belum dapat dilayani oleh industri keuangan tradisional dikarenakan ketatnya peraturan perbankan dan adanya keterbatasan industri perbankan tradisional dalam melayani masyarakat di daerah tertentu, 2) Menjadi alternatif pendanaan selain jasa industri keuangan tradisional di mana masyarakat memerlukan alternatif pembiayaan yang lebih demokratis dan transparan. Sedangkan kekurangan dari fintech adalah: 1) Fintech merupakan pihak yang tidak memiliki lisensi untuk memindahkan dana dan kurang mapan dalam menjalankan usahanya dengan modal yang besar, jika dibandingkan dengan bank. 2) Ada sebagaian perusahaan Fintech belum memiliki kantor fisik, dan kurangnya pengalaman dalam menjalankan prosedur terkait sistem keamanan dan itegritas produknya.

Menurut Bank Indonesia, Perkembangan fintech yang sangat pesat di Indonesia dapat membawa banyak manfaat bagi peminjam, investor maupun perbankan di Indonesia:

a. Bagi peminjam, manfaat yang dapat dirasakan seperti mendorong inklusi keuangan, memberikan alternatif pinjaman bagi debitur yang belum layak 
kredit, prosesnya mudah dan cepat, dan persaingan yang ditimbulkan mendorong penurunan suku bunga pinjaman.

b. Bagi investor fintech, manfaat yang dapat dirasakan seperti alternatif investasi dengan return yang lebih tinggi dengan risiko default yang tersebar di banyak investor dengan nominal masing - masing cukup rendah dan investor dapat memilih peminjam yang didanai sesuai preferensinya.

c. Bagi perbankan, kerjasama dengan fintech dapat mengurangi biaya seperti penggunaan non-traditional credit scoring untuk filtering awal aplikasi kredit, menambah Dana Pihak Ketiga (DPK), menambah channel penyaluran kredit dan merupakan alternatif investasi bagi perbankan.

Beberapa manfaat fintech di Indonesia yang dirangkum dari OJK (2016), di antaranya: 1) Mendorong distribusi pembiayaan nasional masih belum merata di 17.000 pulau, 2) Mendorong kemampuan ekspor UMKM yang saat ini masih rendah, 3) Meningkatkan Inklusi keuangan nasional, 4) Mendorong pemerataan tingkat kesejahteraan penduduk, 5) Membantu pemenuhan kebutuhan pembiayaan dalam negeri yang masih sangat besar.

\subsection{Maqashid Syariah}

Rasyuni (1995) dalam Ismail (2014) mendefinisikan maqashid syariah sebagai tujuan-tujuan yang ditetapkan syari' (Allah) untuk memastikan kemaslahatan hambahamba-Nya. Secara keilmuan, maqashid syariah ini termasuk dalam literatur ilmu ushul figh yang dapat ditinjau dari beberapa ulama ushul figh yang membahas terkait tujuan syariat yang telah ditetapkan oleh syari' (Allah) yaitu Imam al-Harmayn, Imam Ghazali, Imam Syatibi dan Ibn 'Ashur.

Perumusan maqashid syariah pertama kali dibahas dalam buku al-Burhan karya Imam al-Harmayn dalam bab 'illah dan usul. Beliau berpendapat bahwa maqashid syariah dapat dikategorikan menjadi tiga yaitu dharuriyat, hajiyat dan tahsiniyat. Selain itu, beliau juga telah merumuskan dharuriyat al-kubra dalam syariat atau yang lebih dikenal dengan nama maqashid al-khomsah. (Ismail, 2014)

Pada abad 12 Masehi, Imam Ghazali seorang pakar hukum (fikih), doktrin-Islam (akidah), spiritualitas-Islam (tasawuf) dan filsafat berpendapat dalam bukunya syifa alghalil bahwa maqashid syariah dibagi menjadi 2 bagian, yaitu: 1) dini (agama) dan 2) dunyawi (dunia). Adapun untuk pembagian pada kategori dunia, beliau memfokuskan pada 4 hal diantaranya: memelihara diri, memelihara akal, memelihara keturunan dan memelihara harta. Sedangkan untuk kategori agama adalah segala sesuatu yang menahan diri dari perbuatan-perbuatan keji. (Ismail, 2014)

Imam Syatibi yang juga dikenal sebagai Syaikhul Maqasid dalam karyanya alMuwafaqat membagi maqashid syariah dalam dua bagian penting yaitu qasdu al-syari' dan qasdu al-mukallaf. Kemudian qasdu al-syari' diklasifikasikan kembali menjadi empat bagian yaitu: 1) maksud Syari menetapkan syariat, 2) maksud Syari menetapkan syariat pemahaman, 3) maksud Syari menetapkan syariat untuk perintah hukum, dan 4) maksud Syari memasukkan mukallaf dalam hukum-hukum syariat. Berhubungan 
dengan maqashid al-syari' merujuk pada tiga pemeliharaan tujuan-tujuan mendasar manusia yaitu dharuriyat, hajiyat dan tahsiniyat. Sedangkan untuk maqashid al-mukallaf dapat diwujudkan dalam bentuk perilaku atau pelaksanaan yang dibatasi oleh syariat. (Ismail, 2014)

Ibn 'Ashur dilahirkan di Tunisia 1879 dan wafat pada 1973, karyanya yang mashur dalam ilmu maqashid syariah berjudul maqashid al-Syar'iyyah al-Islamiyyah. Beliau memaparkan bagaimana konsep maqashid syariah dan membaginya menjadi dua bagian yaitu: maqashid al-syariah al-amm dan al-khassah. Pertama, maqashid al-syariah al-amm adalah tujuan-tujuan yang ditetapkan oleh syara' pada setiap hukum-hukum syariat. Tujuan ini lebih ditekankan kepada kemaslahatan manusia secara umum seperti keadilan dan kesejahteraan. Kedua, maqashid al-syariah al-khassah adalah hukum-hukum yang dikhususkan pada pembahasan tertentu dari syariat seperti hukum-hukum keluarga, nikah, jinayat dan keuangan. (Ismail, 2014)

Secara keseluruhan, dari empat ulama yang berpendapat tentang maqashid syariah semuanya membedakan antara tingkatan maslahah menjadi tiga yaitu dharuriyat, hajiyat dan tahsiniyat. Maslahah dharuriyyat disebut juga dengan maqashid al-khamsah yaitu agama (al-Din), Jiwa (al-Nafs), Keturunan (al-Nasl), Akal (al-Aql) dan Harta (al-Mal). Maslahah hajiyat untuk menghilangkan kesempitan dan kesulitan dalam penenuhan kebutuhan dasar manusia. Maslahah tahsiniyat adalah segala sesuatu yang bertujuan untuk menjaga kehormatan dari maqashid al-khamsah tersebut. (Ismail, 2014) Dalam industri keuangan dan perbankan syariah, aplikasi maqasid syariah dapat ditemukan dalam penelitian yang dilakukan oleh Bedoui dan Mansour (2013), Jazil dan Syahruddin (2013), Muayyad dan Esya (2016), Rusydiana dan Alparisi (2016), Saoqi (2017), Rusydiana dan Firmansyah (2017) serta Rusydiana dan Sanrego (2018).

\section{METODE PENELITIAN}

Penelitian ini merupakan jenis penelitian deskriptif dengan pendekatan kualitatif yaitu prosedur penulisan yang menghasilkan data deskriptif (uraian terhadap suatu peristiwa atau masalah) berupa kata-kata tertulis dari orang-orang dan perilaku yang diamati tidak secara langsung, atau studi kasus tunggal dan dalam satu lokasi saja. Paradigma kualitatif menekankan pada pemahaman mengenai masalah-masalah dalam kehidupan sosial berdasarkan kondisi realitas atau natural setting yang holistis, kompleks dan rinci (Indiarto dan Bambang, 1999).

Jenis data yang digunakan dalam penulisan ini adalah data sekunder, data sekunder yaitu sumber data penulisan yang diperoleh secara tidak langsung melalui media perantara atau diperoleh dan dicatat oleh pihak lain. Data sekunder umumnya berupa bukti, catatan, atau laporan historis yang telah tersusun dalam arsip (data dokumenter), baik yang dipublikasikan maupun tidak dipublikasikan (Indiarto dan Bambang, 1999).

Teknik yang digunakan untuk mengumpulkan data dalam penelitian ini adalah: 1) Studi pustaka, yaitu serangkaian kegiatan yang berkenaan dengan metode pengumpulan data pustaka, membaca dan mencatat serta mengolah bahan penelitian, 2) Dokumenter, Studi dokumentasi dilakukan dengan jalan membaca laporan-laporan 
penulisan sebelumnya serta artikel yang diakses dari internet, buku maupun jurnal yang sesuai dengan permasalahan. Pada metode ini penulis hanya memindahkan data yang relevan dari suatu sumber atau dokumen yang diperlukan, 3) Diskusi, yaitu cara pengumpulan data dengan melakukan pembicaraan dan pertukaran pikiran dengan orang-orang yang berkompeten dengan obyek yang sedang diteliti guna memecahkan masalah tertentu, 4) Intuitif-Subjektif, merupakan perlibatan pendapat penulis atas masalah yang sedang dibahas. (Ghofar, 1999).

Analisis data merupakan upaya pemecahan masalah penelitian untuk memperoleh jawaban atas permasalahan yang diteliti. (Moeloeng, 2004). Penelitian ini menggunakan analisis maqashid syariah untuk melihat kesesuaian antara inovasi teknologi dalam produk dan layanan keuangan syariah dengan tataran pedoman kebutuhan-kebutuhan saat ini yang sesuai dengan syariat. Pembagian maqashid syariah Maslahah dharuriyyat disebut juga dengan maqashid al-khamsah yaitu agama (al-Din), Jiwa (al-Nafs), Keturunan (al-Nasl), Akal (al-'Aql) dan Harta (al-Mal). Maslahah hajiyat untuk menghilangkan kesempitan dan kesulitan dalam penenuhan kebutuhan dasar manusia. Maslahah tahsiniyat adalah segala sesuatu yang bertujuan untuk menjaga kehormatan dari maqashid al-khamsah tersebut. (Ismail, 2014)

\section{HASIL DAN PEMBAHASAN}

\subsection{Digitalisasi Keuangan Syariah}

Perkembangan keuangan syariah di Indonesia diawali dengan berdirinya salah satu perbankan syariah pada tahun 1992 yaitu Bank Muamalat. Kemudian dua tahun setelah itu tepatnya pada tahun 1994, perusahaan asuransi syariah pertama didirikan yaitu PT Asuransi Takaful Keluarga dan pada tahun 1997 reksa dana syariah pertama di Indonesia mulai diterbitkan. Keuangan syariah lebih identik kepada perbankan syariah karena secara aset perbankan syariah menguasai sekitar 83\% dari total aset seluruh industri keuangan syariah. (Statistik Sistem Keuangan Indonesia, Feb 2017).

Sejak saat itu, perkembangan keuangan syariah mulai berkembang cukup pesat khususnya untuk sektor perbankan syariah di mana beberapa bank konvensional memiliki anak usaha syariah atau unit usaha syariah. Statistik perbankan syariah tahun 2009 menunjukkan bahwa jumlah bank umum syariah (BUS) di Indonesia sebanyak 6 (BUS) dan pada tahun 2010 meningkat menjadi 10 BUS. Data terakhir tahun 2018 menunjukkan bahwa saat ini jumlah BUS di Indonesia ada 14 BUS yang beroperasi.

Selain itu, total aset perbankan syariah setiap tahun mengalami peningkatan yang cukup baik, data OJK menunjukkan pada tahun 2015 total asset perbankan syariah di Indonesia mencapai Rp. 296.262 miliar atau mengalami kenaikan sebesar 9\% dari tahun 2014 sebesar Rp. 272.343 miliar. Tahun 2016, total aset perbankan syariah di Indonesia meningkat signifikan menjadi Rp. 356.504 miliar atau mengalami peningkatan sebesar 20\%, namun pada tahun 2017 pertumbuhan total aset perbankan syariah menurun dari tahun sebelumnya, tercatat persentase pertumbuhan sebesar 19\% atau sekitar Rp. 424.181 miliar. Kecendrungan penurunan pertumbuhan total aset berlanjut kepada tahun 2018 yang hanya sebesar 13\% dari total aset tahun 2017, namun secara nominal total aset perbankan syariah mengalami peningkatan menjadi 
Rp. 477.327 miliar. Namun jika dibandingkan dengan total aset perbankan konvensional pada tahun 2018 yang mencapai Rp. 8.068.346 miliar, rasio aset perbankan syariah pada tahun 2018 hanya sebesar 5,9\%. Data ini membuktikan bahwa aset perbankan syariah masih kecil jika dibandingkan dengan total aset perbankan secara nasional.

Di sisi lain, tingkat market share perbankan syariah di Indonesia masih berada pada level 5\%. Data tahunan yang diumukan oleh OJK bahwa setiap tahun pangsa pasar perbankan syariah mengalami peningkatan namun belum signifikan. Pada tahun 2017, tingkat pangsa pasar perbankan syariah hanya sebesar 5,74\%. Berikut rincian market share perbankan syariah setiap tahun:

\section{Gambar 5. Strategi Nasional Keuangan Inklusif}

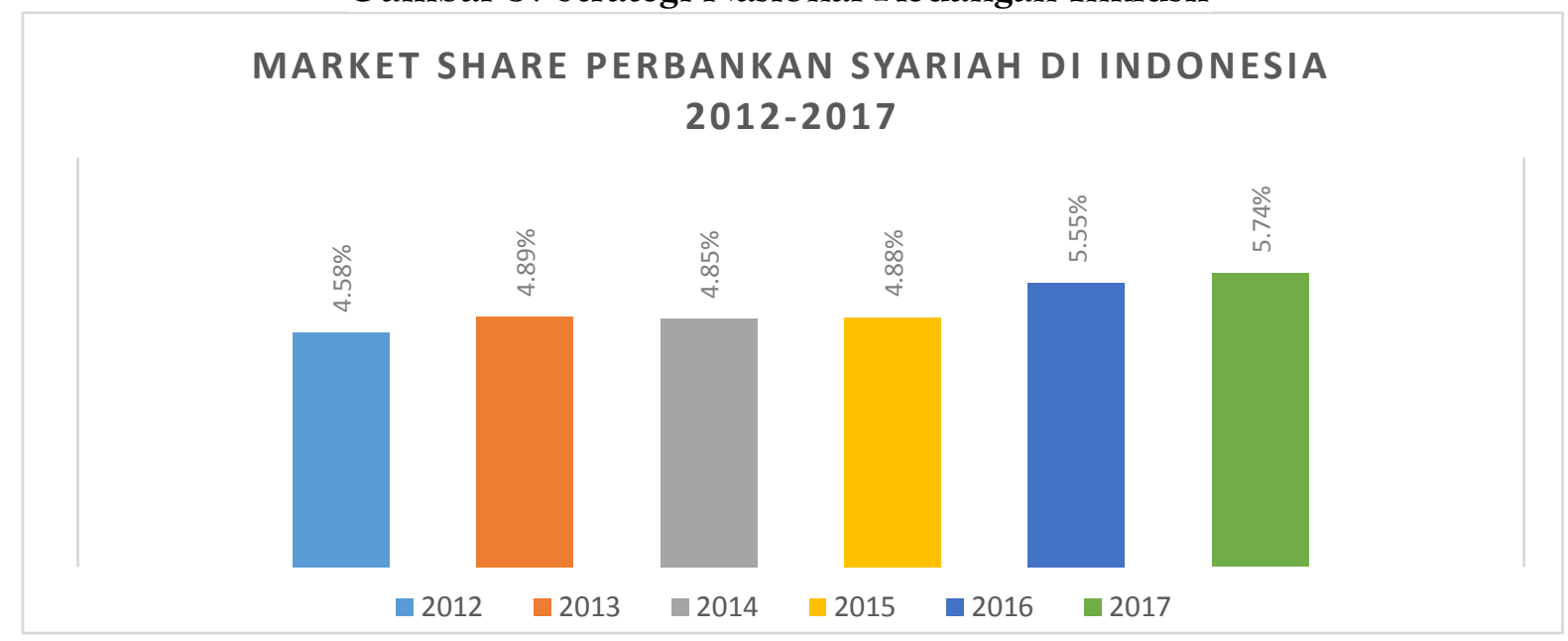

Sumber: Statistik Perbankan Syariah, OJK 2012-2017, data diolah.

Melihat kecendrungan rendahnya rasio aset perbankan syariah terhadap perbankan konvensional dan rendahnya pangsa pasar perbankan syariah serta tingkat literasi dan inklusi keuangan syariah juga rendah, maka dibutuhkan sebuah solusi untuk meningkatkan nilai dan rasio hal-hal tersebut. Nejatullah Siddiqi (2006) dalam evaluasinya menegaskan bahwa ada kebutuhan mendasar yang dirasakan mendesak untuk mengevaluasi apa yang telah terjadi selama tiga dekade terakhir di bidang perbankan dan keuangan Islam.

Evaluasi ini lebih penting daripada tingkat pertumbuhan, kinerja komersial dan pangsa pasar yaitu evaluasi terhadap kontribusi perbankan dan keuangan Islam untuk memperkenalkan dan mempromosikan pemahaman aspek ekonomi dan keuangan dari cara hidup Islam secara keseluruhan. Sebuah survei tentang keadaan seni di bidang perbankan dan keuangan Islam dalam teori dan praktek diharapkan dapat memenuhi kebutuhan itu. Karena secara praktek permasalahan yang masih dihadapi oleh sektor keuangan syariah antara lain keterbatasan suplai produk syariah; keterbatasan akses akan produk keuangan syariah; masih belum optimalnya tingkat literasi keuangan syariah dan tingkat utilitas produk keuangan syariah; keterbatasan sumber daya manusia; perlunya optimalisasi koordinasi dengan para pemangku kepentingan; serta 
perlunya kebijakan jasa keuangan yang selaras dan dapat saling mendukung perkembangan seluruh sektor keuangan syariah.

Transformasi digitalisasi layanan perbankan syariah adalah sebuah keniscayaan. Di era digital seperti saat ini bentuk media sudah beralih ke format online karena mudah diakses oleh siapa saja yang membutuhkan informasi. Masyarakat juga dengan mudahnya berbagi informasi (share) akun sosialnya masing-masing sehingga informasi dan pengetahuan tentang ekonomi dan perbankan syariah akan mudah diterima oleh masyarakat.

Salah satu solusi dari evaluasi tersebut adalah digitalisasi produk dan layanan keuangan syariah. Dengan digitalisasi ini masyarakat dapat dengan mudah mengakses segala informasi terkait produk dan layanan keuangan syariah tanpa terkendala ruang dan waktu. Penulis memiliki inovasi digital untuk produk dan layanan keuangan syariah yang diberi nama "Connected, One Stop Solution". Aplikasi ini dapat mempermudah masyarakat untuk membuat rekening bank syariah tanpa perlu datang ke kantor cabang, kemudian selain produk perbankan syariah, aplikasi ini menawarkan produk keuangan syariah lain seperti asurasi syariah, gadai syariah, reksadana syariah dan saham syariah. Selain itu, untuk keperluan social masyarakat dapat membayar Zakat, Infaq, Shadaqah dan Wakaf di aplikasi ini.

\subsection{Gambaran Umum “Connected”}

Connected merupakan sebuah inovasi teknologi keuangan syariah yang dikhususkan untuk memudahkan nasabah dalam mengakses layanan dan produk keuangan syariah. Connected hanya dikembangkan dalam bentuk mobile aplikasi atau smartphone based yang ditujukan untuk kemudahan akses terhadap layanan dan produk keuangan syariah serta meningkatkan market share keuangan syariah karena era digital saat ini, konsumsi masyarakat terhadap internet semakin berkembang bahkan internet sudah seperti kebutuhan pokok yang tidak bisa ditinggalkan. Maka dari itu, pemanfaatan internet untuk kelanjutan bisnis industri keuangan syariah sudah sangat mendesak untuk dikembangkan. Ada sekitar 20 fitur connected yang dapat diakses oleh masyarakat sehingga cukup dengan satu aplikasi saja, semua kebutuhan dapat diwujudkan. Fitur-fitunya antara lain: rincian, tabungan, pembayaran, pembelian, tarik tunai, pinjaman, zakat, wakaf, cicilan, gadai, resto, travel, asuransi, reksadana, saham, tambah teman, scan kode QR, aktifkan NFC, chatting dan virtual assistant (Rahma).

Adapun rincian fitur yang disediakan oleh connected agar masyarakat dapat menikmati kemudahan layanan keuangan dan produk syariah adalah:

a. Rincian: fitur ini digunakan untuk melihat semua rincian transaksi yang telah dilakukan oleh pengguna aplikasi, saldo rekening dalam bentuk grafik dan dapat melihat sisa saldo.

b. Tabung: fitur ini dikhususnya bagi pengguna yang ingin menyimpan dananya untuk investasi ataupun untuk keperluan-keperluan lainnya. Connected memfasilitasi masyarakat untuk menabung emas, menabung dollar, menabung ibadah (Haji \& Umrah) dan tabungan masa depan seperti tabungan untuk rencana nikah atau tabungan untuk rencana liburan. 
c. Bayar: fitur ini dapat dimanfaatkan untuk melakukan pembayaran tagihantagihan seperti pembayaran pulsa pasca bayar, pembayaran PLN, pembayaran PDAM, pembayaran kartu kredit, pembayaran BPJS dan pembayaran pajak.

d. Beli: Selain tiga fitur sebelumnya, connected juga menyediakan fitur untuk pembelian yang dikhususkan untuk pembelian tiket pesawat, tiket kereta dan pesan hotel bahkan bisa dimanfaatkan juga untuk memesan tiket hiburan (film).

e. Tarik Tunai: satu lagi fitur connected yaitu tarik uang tunai di ATM mana saja tanpa perlu menggunakan kartu debit.

f. Pinjam/Pinjam Modal: bagi masyarakat yang ingin meminjam uang tunai dan membutuhkan dana untuk modal, dapat juga dilakukan hanya dengan menulis keperluan dan jumlah pinjaman yang diinginkan.

g. ZIS: untuk melengkapi kebutuhan rohani dan sosial, connected telah menyiapkan fitur untuk berzakat, infaq dan shadaqah. Masyarakat dapat memilih sendiri lembaga filantropi zis sesuai dengan keinginan masing-masing.

h. Wakaf: fitur ini menjadi fasilitas bagi masyarakat yang ingin menyalurkan dananya untuk sama-sama membangun rumah tahfidz, rumah sehat, masjid dan sekolah.

i. Cicil: fitur lainnya, masyarakat dapat melakukan cicilan pembelanjaan dari berbagai marketplace seperti lazada, tokopedia, blibli, jdid dan shopee tanpa kartu kredit, tanpa riba, tanpa bunga dan tanpa denda.

j. Gadai: fitur ini merupakan fitur yang baru, di mana masyarakat yang ingin menggadaikan barangnya tidak perlu datang ke tempat pegadaian tetapi cukup menggunakan aplikasi connected dengan mengunggah beberapa foto dari barang yang ingin digadaikan sehingga lebih mudah, praktis dan efisien.

k. Resto: fitur ini sangat bermanfaat bagi masyarakat untuk mencari tempat makan yang sedang terkenal sesuai dengan lokasi yang diinginkan, bisa juga memilih jenis makanan yang diinginkan seperti seafood atau makanan lainnya.

1. Travel: fitur ini memudahkan masyarakat mencari destinasi tempat yang sedang tersohor sesuai dengan budget yang diharapkan.

m. Asuransi: fitur investasi lain yang ada di aplikasi connected yaitu asuransi. Masyarakat dapat memilih asuransi yang diinginkan sesuai dengan kebutuhan masing-masing, asuransi yang tersedia seperti: asuransi kesehatan, asuransi kendaraan, asuransi properti dan asuransi pendidikan.

n. Reksa: masyarakat dapat menyalurkan investasinya dengan lebih praktis melalui fitur reksa pada aplikasi connected. Pengelolaan reksa dikelola oleh manajer investasi yang sudah terdaftar di OJK.

o. Saham: bagi masyarakat yang ingin berinvestasi trading dapat juga membeli saham syariah di aplikasi connected.

p. Ajak teman: fitur ini digunakan untuk mengajak orang lain untuk menggunakan aplikasi connected dan menambah teman chat pada aplikasi ini. 
q. Scan QR: digunakan untuk melakukan pembayaran di merchant-merchant yang sudah bekerjasama dengan connected. Aplikasi ini mendukung program cashless yang dicanangkan oleh pemerintah.

r. NFC: fitur ini dapat digunakan untuk pembayaran juga dan dapat digunakan untuk transaksi di bus, kereta dan absensi masuk kerja.

s. Chat: fitur ini digunakan untuk mengirim pesan kepada teman yang sudah terdaftar sebagai pengguna connected dan bisa juga digunakan untuk transfer uang ke sesama pengguna aplikasi ini.

t. Rahma: merupakan virtual assistant yang dapat menjawab semua pertanyaan dan kendala yang dihadapi nasabah. Selain chat, rahma juga dapat bekerja dengan voice recognition.

Beberapa tampilan fitur-fitur aplikasi “Connected, One Stop Solution”:

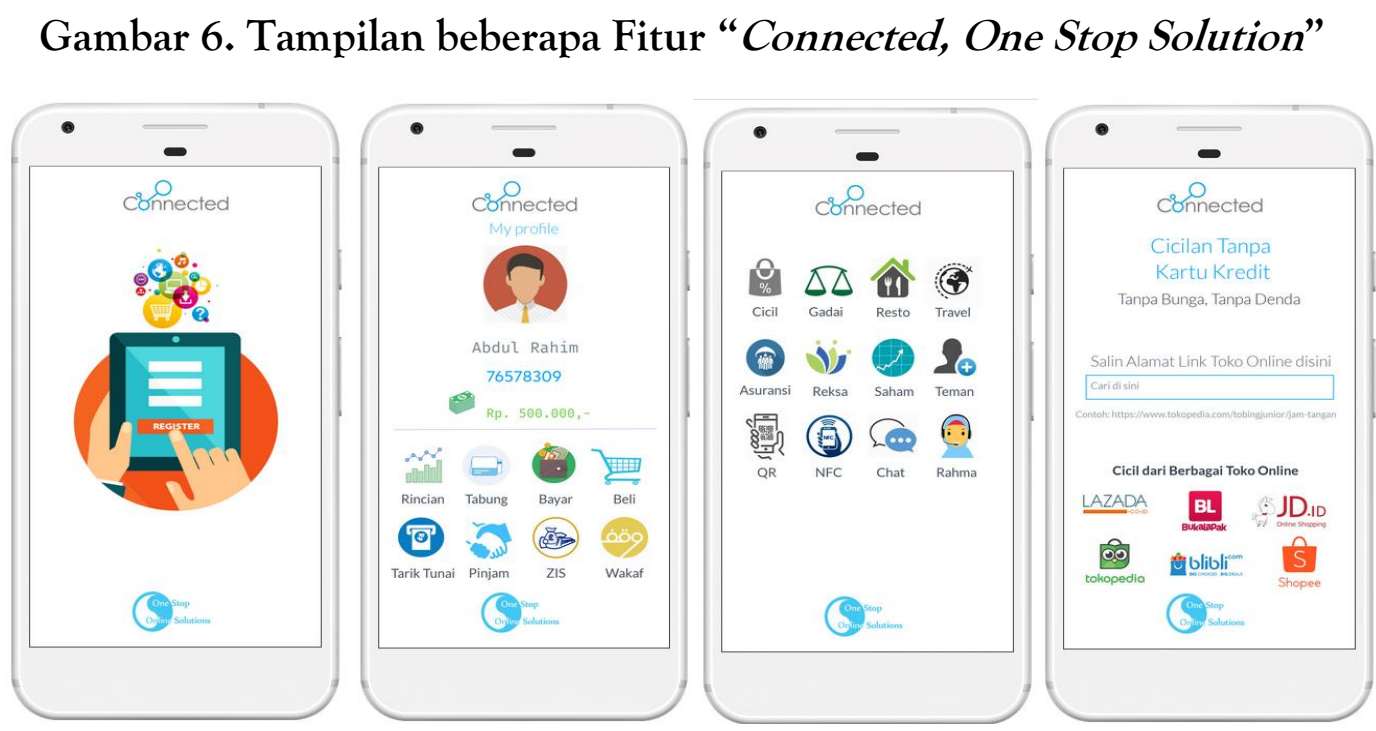

Seacara umum keunggulan aplikasi ini adalah semua fitur yang ada sesuai dengan konsep maqashid syariah dan secara terperinci beberapa keunggulan "Connected" di antaranya: 1) Memudahkan masyarakat untuk memiliki akun tabungan dan investasi keuangan syariah dengan efisien tanpa harus datang ke kantor cabang, 2) Memiliki 20 fitur yang lengkap dalam 1 aplikasi, 3) Mendukung fitur sosial seperti Zakat, Infaq, Shadaqah dan Wakaf, dan 4) Memudahkan masyarakat untuk bertransaksi pembayaran dengan fitur QR. Selain itu, aplikasi ini pun memiliki kekurangan yaitu: 1) koneksi jaringan harus stabil, 2) SDM harus mumpuni dan 3) sistem keamanan pengguna.

\subsection{Analisis Maqashid Syariah pada Aplikasi "Connected"}

Ismail (2014) dalam bukunya maqashid syariah dalam ekonomi islam menyimpulkan bahwa ada tiga tingkatan maslahah dalam maqashid syariah yaitu dharuriyyah, hajjiyat dan tahsiniyyah. Dharuriyyah menjadi prioritas utama untuk menentukan arah dan kebijakan karena maslahah ini terdiri dari lima kategori pokok: 
agama, jiwa, akal, keturunan dan harta. Pembuatan aplikasi keuangan syariah berbasis teknologi pun harus disesuaikan dengan tujuan-tujuan syariah agar tidak melanggar hukum dasar muamalat.

Tujuan dibuatnya aplikasi ini adalah untuk memudahkan masyarakat menggunakan semua produk dan layanan keuangan syariah baik dari tabungan, asuransi, gadai dan lainnya. Selain itu, mengajak masyarakat secara perlahan untuk meninggalkan transaksi-transaksi yang dilarang oleh syariat Islam yaitu riba. Dengan kemudahan akses ini, kontribusi masyarakat terhadap keuangan syariah diharapkan akan semakin meningkat perharinya. Jika melihat kepada market share perbankan syariah yang masih rendah sekitar $8 \%$ dibandingkan dengan perbankan konvensional yang menguasai 92\% pasar keuangan (siaran pers OJK, 2017), maka inovasi-inovasi teknologi keuangan syariah menjadi hal yang harus diwujudkan dan sifatnya menjadi dharuriyyah baik secara agama, jiwa, akal, keturunan dan harta. Kemudahan akses terhadap keuangan syariah termasuk dalam maslahah hajiyat dan fasilitas-fasilitas promosi termasuk dalam maslahah tahsiniyyat.

Inovasi keuangan syariah berbasis teknologi yang dikembangkan penulis dengan nama aplikasi "Connected" diharapkan dapat meningkatkan konstribusi masyarakat terhadap layanan dan produk keuangan syariah di Indonesia. Karena sejatinya, industri perbankan dan keuangan syariah di Indonesia relatif masih lemah dalam aspek inovasi dan layanan produknya (Rusydiana, 2016). Di sisi lain, aplikasi ini dapat digunakan tidak hanya bagi masyarakat muslim tetapi masyarakat non-muslim pun dapat mendaftarkan diri untuk menginstall Connected sehingga akan menambah number of account (noa) pengguna keuangan syariah.

Fitur - fitur yang ada pun disesuaikan dengan tujuan-tujuan dan landasan maqashid syariah agar dalam prakteknya tidak menyimpang dari ajaran agama islam. Pembagian fitur berdasarkan maslahah dharuriyyah sebagai berikut: (Ismail, 2014).

1. Menjaga Agama (Al-Din): maslahah ini berkaitan dengan keimanan seseorang kepada sang pencipta Allah Swt direfleksikan dalam bentuk ibadah-ibadah yang diperintahkan seperti shalat lima waktu, membayar zakat, menunaikan haji dan umrah, melunasi hutang, berwakaf dan kebutuhan - kebutuhan lainnya yang diperlukan untuk meningkatkan keimanan dan memelihara agama islam. Aplikasi Connected mengakomodasi maslahah ini dengan membuat fitur-fitur terkait yaitu membayar zakat, berwakaf dan tabung haji serta umrah.

2. Menjaga Jiwa (Al-Nafs): maslahah ini berkaitan dengan menjaga kesehatan jiwa seseorang dan menjauhkan dari berbagai penyakit yang berdampak kepada kesejahteraan. Kebutuhan terhadap asupan makanan yang bergizi dan menyehatkan untuk memeliharan jiwa agar tetap sehat. Dalam konteks keuangan, takaful menjadi akses utama untuk memperoleh fasilitas kesehatan. Aplikasi Connected memfasilitasi maslahah ini dengan fitur asuransi kesehatan. Masyarakat dapat dengan mudah menikmati fasilitas asuransi kesehatan pada aplikasi ini.

3. Menjaga Keturunan (Al-Nasl): maslahah ini berkaitan dengan pernikahan yang menjadi jalan syariah (sunnah) dalam memperoleh keturunan shaleh dan shalehah. Pernikahan merupakan fitrah manusia dan menjadi wajib hukumnya bila seseorang 
sudah mampu untuk menikah karena dengan menikah ini dapat menjaga dari perbuatan-perbuatan keji. Rasulullah SAW bersabda: "Wahai para pemuda! Barang siapa di antara kalian berkemampuan untuk menikah, maka menikahlah, karena menikah itu lebih menundukkan pandangan dan lebih membentengi kemaluan. Dan barang siapa yang tidak mampu, maka hendaklah ia berpuasa karena puasa dapat membentengi diri." (HR. Muslim No 1400) Connected memfasilitasi maslahah ini dengan fitur tabung masa depan di mana masyarakat dapat menabung untuk keperluan masa depannya termasuk rencana untuk menikah.

4. Menjaga Akal (Al-'Aql): maslahah ini berkaitan dengan ilmu sebagai landasan dasar dari beragama. Seseorang yang tidak berilmu tidak akan dapat berfikir tentang keutamaan - keutamaan agama Islam yang rahmatan lil 'alamin. Allah SWT sangat memuliakan orang yang berilmu, dalam surat Al-Mujaadilah ayat 11, Allah SWT berfirman: "Niscaya Allah akan meninggikan orang - orang yang beriman di antara kalian dan orang - orang yang diberi ilmu beberapa derajat." Fitur Connected yang sesuai dengan maslahah ini yaitu asuransi pendidikan dan tabung masa depan. Fitur ini memfasilitasi setiap masyarakat yang ingin melanjutkan pendidikannya sampai ke jenjang yang paling tinggi.

5. Menjaga Harta (Al-Mal): harta merupakanalat tukar untuk mendapatkan kebutuhan-kebutuhan pokok manusia seperti bahan makanan pokok, dengan harta seseorang dapat memenuhi kebutuhan tersebut. Harta dapat diperoleh dari perdagangan, propesi pekerjaan atau warisan, dalam Islam harta harus didapatkan dari cara-cara halal yang terhindar dari segala unsur gharar, maysir, tadlis, ikhtikar dan riba. Jika dikaitkan dengan keuangan, harta dapat juga diperoleh dari jalur investasi di pasar keuangan dan pasar modal. Selain itu, untuk menjaga harta agar tetap aman diperlukan skema takaful yang menjaga harta dari kehilangan atau kecelakaan. Aplikasi Connected memfasilitasi hal ini dengan adanya fitur investasi reksa, saham dan tabung emas serta untuk takaful Connected menyiapkan fitur asuransi kecelakaan, asuransi kendaraan dan asuransi properti.

Maslahah hajiyat mempunyai fungsi untuk menghilangkan kesempitan dan kesulitan dalam pemenuhan kebutuhan-kebutuhan dasar (dharuriyyat) manusia (Ismail, 2014). Konteks maslahah ini dengan keuangan atau pengelolaan harta dapat direalisasikan dengan alokasi kebutuhan yang mempermudah aktifitas ekonomi seperti pembelian kendaraan, pembelian rumah, pembelian emas dan lainnya. Fitur yang memfasilitasi maslahah hajiyat pada aplikasi Connected yaitu fitur tabung dollar, fitur cicilan, fitur bayar, fitur gadai, fitur resto, fitur travel, scan QR dan NFC. Berbagai macam fitur ini dapat menjadi jalan agar memudahkan masyarakat terhadap kebutuhan dasar atau pokoknya.

Terkahir, maslahah tahsiniyat atau kamaliyat yaitu maslahah pelengkap yang tujuannya tidak untuk merealisasikan maqashid dharuriyyah dan maslahah tahsiniyat melainkan untuk menjaga kehormatan dari maqashid dharuriyyah sendiri. Pada level ini masyarakat difokuskan kepada tatacara atau etika dalam pengelolaan harta dan 
bermuamalat. Fitur pada aplikasi Connected yang masuk dalam maslahah ini adalah tambah teman, chat dan rahma (helpdesk).

Kombinasi antara tiga maslahah utama (dharuriyyah, hajiyat dan tahsiniyat) yang telah dirumuskan oleh para ulama dan pembagian maslahah dharuriyyah menjadi 5 kategori menjadi landasan utama dalam pembuatan konsep aplikasi Connected, di mana perumusan fitur - fitur yang ada pada aplikasi disesuaikan dengan maqashid syariah. Sehingga dalam prakteknya nanti, tidak ada layanan dan produk yang keluar dari norma dan ajaran Islam. Pada dasarnya pembuatan aplikasi ini diharapkan dapat mempermudah masyarakat dalam mengakses layanan dan produk keuangan syariah yang secara tingkat inklusi dan tingkat literasi masih jauh tertinggal dari tingkat inklusi dan tingkat literasi keuangan konvensinal. Hal ini menjadi penyebab market share keuangan syariah di Indonesia tumbuh stagnan hanya sekitar $8 \%$ saja. (siaran pers OJK, 2017).

Selain itu, semua fitur yang ada pada aplikasi Connected telah mencerminkan sample kebutuhan - kebutuhan masyarakat dengan akses yang sangat mudah, hanya dengan memiliki smartphone dan koneksi internet maka semua masyarakat dapat menggunakan aplikasi ini. Keungtungan lainnya, sistem yang diterapkan dalam setiap transaksi menggunakan sistem berlandaskan syariah yaitu sistem yang terhindar dari segala macam unsur gharar, maysir, tadlis, ikhtikar dan riba. Maka dengan adanya digitalisasi keuangan syariah seperti Connected, masyarakat akan lebih mudah mengakses layanan dan produk keuangan syariah secara umum. Berikut rincian fitur Connected yang sesuai dengan maqashid syariah:

Tabel 1. Fitur Connected \& Maqasid Syariah

\begin{tabular}{|l|c|l|}
\hline \multicolumn{1}{|c|}{ Maslahah } & Kategori & \multicolumn{1}{c|}{ Fitur Connected } \\
\hline \multirow{4}{*}{ Dharuriyyah } & Agama & Zakat, Wakaf dan Tabung Haji Umrah \\
\cline { 2 - 3 } & Jiwa & Asuransi Kesehatan \\
\cline { 2 - 3 } & Keturunan & Tabung Masa Depan \\
\cline { 2 - 3 } & Akal & Asuransi Pendidikan dan Tabung Masa Depan \\
\cline { 2 - 3 } Hajiyat & Harta & $\begin{array}{l}\text { Reksa, Saham, Tabung Emas, Asuransi Kendaraan, } \\
\text { Asuransi Kecelakaan dan Asuransi Properti }\end{array}$ \\
\hline Tahsiniyat & $\begin{array}{l}\text { Bayar, Beli, Tarik Tunai, Pinjam/Pinjam Modal, } \\
\text { Cicil, Gadai, Resto, Travel, Scan QR dan NFC. }\end{array}$ \\
\hline
\end{tabular}

Sumber: diolah penulis

\subsection{Implikasi Pengembangan Connected terhadap Keuangan Syariah}

Adanya Connected sebagai inovasi teknologi untuk keuangan syariah memiliki pengaruh yang positif bagi perkembangan keuangan syariah di Indonesia baik industri keuangan bank ataupun industri keuangan non bank, di antaranya:

\section{a. Mendukung Peningkatan Inklusi Keuangan Syariah.}

Digitalisasi layanan dan produk keuangan syariah merupakan salah satu bentuk usaha untuk meningkatkan tingkat kesadaran masyarakat akan kehadiran keuangan syariah di Indonesia. Selain itu, dengan kemudahan teknologi saat ini 
yang dikembangkan melalui aplikasi Connected masyarkat dapat dengan mudah mengakses layanan dan produk keuangan syariah di mana pun dan kapan pun mereka butuhkan dengan tambahan fitur-fitur yang sesuai dengan maqashid syariah. Maka adanya kemudahan akses masyarakat terhadap keuangan syariah ini melalui aplikasi Connected akan berdampak besar pada peningkatan tingkat inklusi keuangan syariah di Indonesia. (OJK, 2016).

b. Meningkatkan Literasi Keuangan dengan Digitalisasi Layanan dan Produk Keuangan Syariah.

Tingkat penggunaan smartphone dan internet yang terus mengalami peningkatan setiap tahun, menjadi sebuah momen yang harus dimanfaatkan oleh semua sektor industri tidak terkecuali industri keuangan syariah. Dengan teknologi informasi yang semakin terbuka dan dengan adanya aplikasi yang memudahkan masyarakat terhadap akses keuangan syariah (Connected), maka masyarakat akan mengetahui layanan dan produk keuangan syariah yang dapat memfasilitasi setiap kebutuhan - kebutuhan. Selain itu, dengan banyaknya fitur yang ada pada Connected ini, masyarakat akan semakin memahami bahwa keuangan syariah memiliki layanan dan produk yang sangat beragam dan tidak kalah dengan industri keuangan konvensional. (OJK, 2016).

\section{c. Meningkatkan Pangsa Pasar Keuangan Syariah}

Aplikasi Connected memiliki fitur-fitur yang sangat beragam sehingga pilihan untuk menggunakan produk dan layanan keuangan syariah bervariasi. Dengan kemudahan registrasi dan penggunaan aplikasi ini diharapkan masyarakat dapat dengan mudah mengakses segala informasi yang berkaitan dengan keuangan syariah. Informasi ini membantu masyarakat untuk menyimpan dananya dan melakukan transaksi menggunakan produk dan layanan keuangan syariah. Maka diharapkan aplikasi ini dapat membantu meningkatkan pangsa pasar keuangan syariah menjadi lebih besar dan produktif.

\section{d. Mendukung Program Pemerintah "Gerakan Nasional Non Tunai".}

Pemerintah mencanangkan program nasional non tunai, di mana semua lapisan masyarakat diajak untuk meminimalisir penggunaan uang tunai untuk transaksi pembelian dan penjualan. Sebaliknya masyarkat diharapkan untuk menggunakan aplikasi atau fitur-fitur pembayaran non tunai seperti mobile banking ataupun pembayaran menggunakan kartu. Connected dalam pengembangannya sangat mendukung program pemerintah ini, di mana setiap masyarakat dapat menggunakan fitur scan QR dan NFC untuk melakukan pembayaran-pembayaran. Selain itu, Connected pun sudah menyediakan menu pembayaran PLN, Pulsa dan PDAM untuk kemudahan masyarakat.

e. Mendukung Kebutuhan - Kebutuhan Halal sesuai dengan Maqashid Syariah Berbeda dengan aplikasi crowdfunding dan peer to peer lainnya yang masih menggunakan sistem konvensional berbasis bunga, Connected mengembangkan sistem yang sesuai dengan transaksi - transaksi halal dan syar'i. Sehingga masyarakat tidak perlu khawatir terhadap unsur gharar, maysir, tadlis, ikhtikar dan riba. 


\section{PENUTUP}

Dari pembahasan-pembahasan sebelumnya, maka dapat disimpulkan beberapa hal berikut:

a. Penulis memberikan solusi inovasi digital untuk meningkatkan tingkat literasi dan inklusi keuangan syariah di Indonesia yaitu dengan membuat aplikasi "Connected, One Stop Solution". Aplikasi ini memfasilitasi masyarakat dengan 20 fitur di antaranya: menabung (tabung biasa, tabung emas dan tabung umrah haji), berinvestasi (asuransi syariah, reksadana syariah dan saham syariah) serta menunaikan kewajiban dan berdonasi (Zakat, Infaq, Shadaqah dan Wakaf).

b. Kesesuaian ke-20 fitur Connected dengan konsep maqashid sharia (dharuriyyah, hajiyat dan tahsiniyat). Maslahah dharuriyyah dibagi menjadi 5 kategori: 1) Agama, 2) Jiwa, 3) Keturunan, 4) Akal, dan 5) Harta. Fitur - fitur yang termasuk dalam maslahah dharuriyyah: 1) Agama: Zakat, Wakaf dan Tabung Haji Umrah, 2) Jiwa: Asuransi Kesehatan, 3) Keturunan: Tabung Masa Depan, 4) Akal: Asuransi Pendidikan dan Tabung Masa Depan, dan 5) Harta: Reksa, Saham, Tabung Emas, Asuransi Kendaraan, Asuransi Kecelakaan dan Asuransi Properti. Fitur yang termasuk maslahah hajiyat yaitu Bayar, Beli, Tarik Tunai, Pinjam, Cicil, Gadai, Resto, Travel, Scan QR dan NFC serta fitur yang termasuk maslahah tahsiniyat yaitu Tambah Teman, Chat dan Rahma.

c. Implikasi aplikasi Connected terhadap keuangan syariah: 1) Mendukung Peningkatan Inklusi Keuangan Syariah, 2) Meningkatkan Literasi Keuangan dengan Digitalisasi Layanan dan Produk Keuangan Syariah, 3) Meningkatkan Pangsa Pasar Keuangan Syariah, 4) Mendukung Program Pemerintah "Gerakan Nasional Non Tunai” dan 5) Mendukung Kebutuhan - Kebutuhan Halal sesuai dengan Maqashid Syariah.

Dari kesimpulan tersebut, ada beberapa saran dan rekomendasi yang penulis ajukan:

a. Inovasi digitalisasi fintech merupakan sebuah keniscayaan, maka seyogyanya setiap industri keuangan syariah dapat mempersiapkan inovasi-inovasi digital untuk memudahkan akses masyarakat terhadap produk dan layanan keuangan syariah.

b. Inovasi digital ini membutuhkan sumber daya manusia (SDM) yang unggul dalam mengombinasikan konsep akad-akad syariah dengan teknologi, maka industri keuangan syariah perlu membuat pelatihan-pelatihan untuk SDM.

c. Pemerintah dalam hal ini Otoritas Jasa Keuangan (OJK) harus membuat peraturanperaturan yang mendukung inovasi digital keuangan syariah dan mengharuskan industri keuangan syariah memiliki inovasi produk dan layanan keuangan syariah secara digital. 


\section{DAFTAR PUSTAKA}

Al-Qur'an Al-Karim dan terjemahannya. 2010. Kementrian Agama RI. Bandung: Sygma.

Bank Indonesia. 2014. Booklet Keuangan Inklusif. Departmen Pengembangan Akses Keuangan dan UMKM Bank Indonesia.

Bank Indonesia. 2018. Program Keuangan Inklusif. https://www.bi.go.id/id/perbankan/keuanganinklusif/program/Contents/defa ult.aspx.

Bedoui, H., and Mansour, W. 2013. "Islamic banks performance and Maqasid alShariah" Paper presented to the 9th Asia-Pacific Economic Association Conference, Osaka Japan, July 27-28.

Chuen, D.L.K., and Teo, E.G.S. 2015, "Emergence of fintech and the LASIC principles", The Journal of Financial Perspectives: Fintech, Winter 2015, pp. 24-37.

Databoks katadata. 2018. Berapa Jumlah Pengguna Internet di Indonesia. https://databoks.katadata.co.id/ datapublish/2018/02/20/berapa-jumlahpengguna-internet-di-indonesia.

E-Marketer. 2017. Internet Users in Select Countries Who Would Share* Their Transaction Data in Exchange for More Personalized Banking Service. www.emarketer.com.

Finanssialan keskusliitto 2015. Muuttuvatyö finanssialalla. Cited 6.12 .2016 \& 17.1.2017, http://www.finanssiala.fi/materiaalit/Muuttuva_tyo_finanssialalla.pdf

Gartner 2016. Digitalization. Cited 28.11.2016, http://www.gartner.com/itglossary/ digitalization/

Ghofar, Abdul. 1999. Analsis Implikasi Pemikiran dan Penafsiran Akuntansi dari Paradigma Mainstream Barat dan Paradigma Islam dalam Kerangka Analisis Konsep TAO (Studi Kualitatif Komparatif Akuntansi Mainstream dan Akuntansi Alternatif dalam Pembentukan Akuntansi Humanis. Skripsi (S1). Jurusan Akuntansi, Fakultas Ekonomi, Universitas Brawijaya, Malang.

Hadad, Muliaman, D. 2017. Financial Technology (FinTech) di Indonesia. Kuliah Umum tentang FinTech, Indonesia Banking School.

Indiarto, Nur dan Bambang Supomo. 1999. Metodologi Penelitian Bisnis untuk Akuntansi dan Manajemen. BPFE : Yogyakarta.

Ismail, Nurizal. 2014. Maqashid Syariah dalam Ekonomi Islam. Cetakan I, Smart WR: Yogyakarta.

Jazil, T., and Syahruddin. 2013. "The performance measures of selected Malaysian and Indonesian Islamic banks based on the Maqasid al-Shariah approach", Journal Ijtihad, Vol.7, No.2.

Koiranen, Ilkka, Räsänen, Pekka, Södergård, Caj 2010. Mitä digitalisaatio on tarkoittanut kansalaisen näkökulmasta?*. Talous ja yhteiskunta, 3, p. 24-29.

Moeloeng, Lexy J. 2004. Metodologi Penelitian Kualitatif. PT. Remaja Rosdakarya : Bandung. 
Muayyad, D.M., and Esya, L. 2016. "Implementation of Maqasid shariah in Islamic financial institution in Indonesia”, International Scholarly and Scientific Research and Innovation, Vol.3, No.9.

Mohammad Nejatullah Siddiqi .2006. Islamic Banking and Finance in Theory and Practice: A Survey of State of the Art, Islamic Economic Studies.

Otoritas Jasa Keuangan. 2017. Siaran Pers Market Share Keuangan Syariah. SP 102/DHMS/OJK/X/2017. www.ojk.go.id.

Otoritas Jasa Keuangan. 2017. Survei Nasional Literasi dan Inklusi Keuangan 2016. www.ojk.go.id.

Pollari, I. 2016, "The rise of fintech: Opportunities and challenges”, The Finsia Journal of Applied Finance, Issue 3, 2016.

Rusydiana, Aam S. 2018. "Developing Islamic financial technology in Indonesia". Hasanuddin Economics and Business Review, Vol. 2, No 2, pp.143-152.

Rusydiana, Aam S. 2016. "Analisis masalah pengembangan perbankan syariah di Indonesia: Aplikasi metode analytic network process”. Esensi: Jurnal Bisnis dan Manajemen, Vol. 6, No. 2, pp.237-246.

Rusydiana, Aam S., and Yulizar D. Sanrego, 2018. "Mesuring the performance of Islamic banking in Indonesia: An application of Maslahah efficiency quadrant (MEQ)". Journal of Monetary Economics and Finance, Vol 3 Special Issue, pp.103. 130.

Rusydiana, Aam S, and Irman Firmansyah, 2017. "Efficiency versus Maqasid sharia index: An application on Indonesia Islamic bank". Shirkah Journal of Economics and Business, Vol 2 No 2.

Rusydiana, Aam S, and Salman Al Parisi, 2016. "The measurement of Islamic bank performance: A study using maqasid index and profitability". Global Review of Islamic Economics and Business, Vol. 4, No. 1, pp.1-14.

Sanjana, I Made dan Nursechafia. 2016. "Inklusi Keuangan dan Pertumbuhan Inklusif: Analisis antar Provinsi di Indonesia”. Buletin Ekonomi Moneter dan Perbankan, Vol. 18, No. 3, Januari 2016.

Saoqi, A.A.Y. 2017. "Analyzing the performance of Islamic banking in Indonesia and Malaysia: Maqasid index approach”, Jurnal Ekonomi Islam, Vol. 8, No.1.

Schinkel, T. 2000, The deepening of office digitization, Office Solutions, vol. 17, no. 10, pp. 34-39.

Schumann, C. \& Tittmann, C. 2015, Digital Business Transformation in the Context of Knowledge Management, Academic Conferences International Limited, Kidmore End, 09, pp. 675.

Sharing Vision Survey. 2015. Peluang Emas Internet Banking. https://sharingvision.com/ peluang -emas-internet-banking.

Statistik Perbankan Syariah. 2012-2018. Otoritas Jasa Keuangan, www.ojk.go.id.

Statistik Sistem Keuangan Indonesia, 2017. Bank Indonesia, www.bi.go.id.

The Global Findex Database. 2017. World Bank, Full Report. https://globalfindex.worldbank.org/ 
The Consultative Group to Assist the Poor (CGAP GPFI). 2018. Financial Inclusion. http://www.cgap.org/topics/financial-inclusion.

Webster, I. and Pizalla, J. 2015. "Fintech: Are banks responding appropriately?" EY Publication 2015.

Zimmerman, Eilene. 2016. The Evolution of FinancialTechnology. New York: The New York Times. 